\title{
RESEARCH PAPER \\ Characteristics of banana fruits (Musa spp. AAA, cv. Nanica) treated with cytokinin and gibberellin
}

\author{
Juliana D. Lima, Jéssica Santa Rosa, Eduardo N. Gomes, Danilo E. Rozane, \\ and Silvia H. Modenese-Gorla da Silva \\ Universidade Estadual Paulista "Júlio de Mesquita Filho", Câmpus Experimental de Registro, 11.900-000, \\ Registro. Estado de São Paulo, Brazil.
}

\begin{abstract}
J.D. Lima, J. Santa Rosa, E.N. Gomes, D.E. Rozane, and S.H. Modenese-Gorla da Silva. 2016. Characteristics of banana fruits (Musa spp. AAA, cv. Nanica) treated with cytokinin and gibberellin. Cien. Inv.Agr. 43(2):223-232. The aim of this study was to analyze the effect of cytokinin and gibberellin on the characteristics of banana fruits (Musa spp. AAA, cv. Nanica) as a function of the formation period and position in the bunch. A completely randomized, $2 \times 5$ factorial design was adopted consisting of two bunch development periods (summer and winter) and five treatments as well as the same arrangement in a split plot with the $2 \times 5$ factorial arrangement as the plot and the position of the hand in the bunch (basal, middle and apical) as the subplot. Treatments consisted of spraying twice with either water, $150 \mathrm{mg} \mathrm{L}^{-1}$ of kinetin, 200 $\mathrm{mg} \mathrm{L}^{-1}$ of gibberellic acid, $100 \mathrm{mg} \mathrm{L}^{-1}$ of kinetin plus $200 \mathrm{mg} \mathrm{L}^{-1}$ of gibberellic acid or $200 \mathrm{mgL}^{-1}$ of kinetin plus $200 \mathrm{mg} \mathrm{L}^{-1}$ of gibberellic acid, all of which were applied from the fourth to the last hand of the bunch. The bunch formation period influenced the filling time, the mass of the bunch and the stalk, the number and the mass of the hands, the number of fruits per hand, fruit size, and the position of the fruit in the bunch as well as the time postharvest shelf life, mass loss, peel color, $\mathrm{pH}$, the soluble solids content and the titratable acidity of the pulp. As applied, the cytokinin and gibberellin did not influence the yield or fruit size, but bunch position had a strong influence on the size and number of fruits per hand.
\end{abstract}

Key words: Growth regulators, intra-bunch variability, source-sink relationship.

\section{Introduction}

The banana fruit (Musa spp.) is an important horticultural crop in tropical and sub-tropical areas of the world that is rich in carbohydrate compounds (ascorbic acid, $\beta$-carotene and soluble

Received May 15, 2015. Accepted March 21, 2016. Corresponding author: judlima@registro.unesp.br sugars), phenols, folic acid and minerals, such as potassium, calcium, phosphorus, magnesium and zinc (Huang et al., 2014).

Within-bunch (inflorescence) variability in banana fruit mass is of great importance; distal fruits (at the bottom of the bunch) are 30 to $40 \%$ smaller than the basal fruits at the top (Jullien et al., 2001a). Large quantities of photosynthates are moved from 
the source to the sink, i.e., from the leaves to the developing bunches (Mulagund et al., 2015), and the competition for assimilates between fruits determines their size and quality (Jullien et al., 2001b). Thus, strategies to standardize fruit size are of great interest because fruit mass and size (length and diameter) are important commercial criteria for marketing bananas for export.

Two key determinants of organ size are cell number and cell size (Guo and Simmons, 2011), which result from cell division, cell expansion or a coordinated series of cell divisions and expansions, so the application of plant hormones can regulate development and maturation as well as improve the fruit quality of various plant species (Marzouk and Kassem, 2011; Zhang and Whiting, 2011). Among the plant hormones that are related to positive effects on developing fruit are gibberellin, which induces parthenocarpic fruit and stimulates cell expansion (Zhang and Whiting, 2013; Niu et al., 2015), and cytokinin, which increases fruit size by affecting cell division and/or cell expansion (Zhang and Whiting, 2011; Ding et al., 2013) and promotes sucrose accumulation by increasing the sink strength of the parthenocarpic fruit (Li et al., 2011). These compounds also exhibit synergistic effects on fruit growth (Zhang and Whiting, 2011; 2013; Ding et al., 2013).

In Musa ssp., the application of gibberellin to the bunch has been shown to promote increased mass and fruit size (Kumar et al., 2011; Biwas and Lemtur, 2014), but there are no reports in the literature on the action of cytokinin alone or in combination with gibberellin on banana fruit production and quality. However, many studies have shown that fruit growth and development strongly depend on the coordinated action of these two plant hormones. Thus, the aim of this study was to analyze the effect of cytokinin and gibberellin on the characteristics of banana fruits (Musa spp. AAA, cv. Nanica) as a function of the formation period and the position in the bunch.

\section{Materials and methods}

Field experiments using banana (Musa spp. AAA group, Cavendish subgroup, cv. Nanica) were conducted at Registro in the southern region of São Paulo, Brazil (24 $28^{\prime} 17^{\prime \prime}$ 'S $47^{\circ} 50^{\prime} 39^{\prime \prime}$ W; 20 masl). The plants were raised by tissue culture and planted in June 2008. According to the Köppen classification, the region's climate is humid tropical without a defined dry season (Af) (Alvares et al., 2013), and the predominant soil in the experimental area was a Typic Hapludox Oxisol (Soil Survey Staff, 2010). Analysis of the surface layer (0-0.2 m) was carried out before the experiment with the following results: $\mathrm{pH}\left(\mathrm{CaCl}_{2}\right)$, 5.9; $\mathrm{Al}$ (exchangeable), $0 \mathrm{cmol}_{\mathrm{c}} \mathrm{dm}^{-3} ; \mathrm{Ca}+\mathrm{Mg}$, $10 \mathrm{cmol}_{\mathrm{c}} \mathrm{dm}^{-3} ; \mathrm{P}$ (resin), $12.5 \mathrm{mg} \mathrm{dm}^{-3} ; \mathrm{K}, 125 \mathrm{mg}$ $\mathrm{dm}^{-3} ; \mathrm{S}^{-\mathrm{SO}_{4}} ; 6.8 \mathrm{mg} \mathrm{dm}^{-3} ; \mathrm{B}, 0.30 \mathrm{mg} \mathrm{dm}^{-3} ; \mathrm{Cu}$, $4.5 \mathrm{mg} \mathrm{dm}^{-3} ; \mathrm{Fe}, 55 \mathrm{mg} \mathrm{dm}^{-3} ; \mathrm{Mn}, 122.5 \mathrm{mg} \mathrm{dm}^{-3}$; $\mathrm{Zn}, 19,5 \mathrm{mg} \mathrm{dm}^{-3}$; organic matter, $28 \mathrm{~g} \mathrm{dm}^{-3}$; base saturation, $85 \%$; cation exchange capacity, 13.4 $\mathrm{cmol}_{\mathrm{c}} \mathrm{dm}^{-3}$; clay, $350 \mathrm{~g} \mathrm{~kg}^{-1}$; silt, $130 \mathrm{~g} \mathrm{~kg}^{-1}$ and sand, $400 \mathrm{~g} \mathrm{~kg}^{-1}$.

A completely randomized $2 \times 5$ factorial design was used, in which two bunch formation periods (summer and winter) and five growth regulator treatments were used as factors. A $2 \times 5$ split plot factorial design was also used, in which the bunch formation periods and the growth regulator treatments were factors and the position of the hand on the bunch (basal, median and apical) was the subplot. Ten replicates were performed for both designs.

The basal, median and apical positions corresponded to the $1^{\text {st }}, 4^{\text {th }}$ and last hand of the bunch, respectively. The treatments consisted of two pulverizations with water (control), $150 \mathrm{mg} \mathrm{L}^{-1}$ kinetin (KIN 150), $200 \mathrm{mg} \mathrm{L}^{-1}$ of gibberellic acid (GA 200), $100 \mathrm{mg} \mathrm{L}^{-1}$ of kinetin plus $200 \mathrm{mg} \mathrm{L}^{-1}$ of gibberellic acid (KIN $100+$ GA 200) and 200 $\mathrm{mg} \mathrm{L}^{-1}$ of kinetin plus $200 \mathrm{mg} \mathrm{L}^{-1}$ of gibberellic acid (KIN $200+$ GA 200) applied from the fourth to the last hand of the bunch. X-Cyte ${ }^{\circledR}$ (Stoller, Houston, Texas, USA), containing $450 \mathrm{~g} \mathrm{~L}^{-1}$ kinetin, 
and Pro Gibb ${ }^{\circledR}$ (Sumitomo, São Paulo, São Paulo, Brazil), containing $100 \mathrm{~g} \mathrm{~kg}^{-1} \mathrm{GA}_{3}$, were used as the sources of the growth regulators, and Tween $\AA$ 20 (Sigma Aldrich, Saint Louis, Missouri, USA) $(0.1 \%)$ was added to the spraying solutions. The spray jet was directed from the $4^{\text {th }}$ hand to the tip of the bunch, and $0.12 \mathrm{~L}$ of the treatment solution was used. The spraying occurred on December 21, 2012 and January 27, 2013 (summer) and on June 17, 2013 and July 28, 2013 (winter). Any other agricultural practices were the same as those used for the other plants in the field.

Bunches were harvested when the fruits from the last hand reached $3 \mathrm{~cm}$ in diameter, and the number of hands, the mass of the bunch and the mass of the stalk were recorded. The $1^{\text {st }}, 4^{\text {th }}$ and last hands of the bunch were weighed, and the number, mean diameter and length of the fruits in each hand were noted.

The $4^{\text {th }}$ hand was stored at $25^{\circ} \mathrm{C}$ until the fruits were fully ripened, i.e., stage 6 of the Von Loesecke scale (1950) which corresponds to a completely yellow peel color. The fruits were evaluated in terms of (a) postharvest life or, rather, time between harvest and complete maturity; (b) mass loss, calculated by the equation $\mathrm{kg}$ water lost $/ \mathrm{kg}$ initial mass of the fruit; and (c) peel color measured at four points around the equatorial region on each fruit using a reflectance colorimeter (Chroma meter, Konica Minolta, Osaka, Osaka, Japan) equipped with a CR-300 measuring head with a D65 light source. Color was recorded using a CIE $\mathrm{L}^{*}, \mathrm{a}^{*}$ and $\mathrm{b}^{*}$ scale, in which $\mathrm{L}$ denotes lightness or darkness; $\mathrm{a}^{*}$ indicates a green to red color; and $b^{*}$ indicates a blue to yellow color. The instrument was calibrated with a standard white tile prior to measurements. Numerical L*, $a^{*}$ and $b^{*}$ values were converted to hue angle $\left[\mathrm{H}=\tan ^{-1}\left(\mathrm{~b}^{*} / \mathrm{a}^{*}\right)\right]$ and chromaticity $\left[\mathrm{C}^{*}=\left(\mathrm{a}^{* 2}+\mathrm{b}^{* 2}\right)^{1 / 2}\right]$. Additional parameters included (d) $\mathrm{pH}$, which was measured using a $\mathrm{pH}$-meter after homogenization of pulp with deionized water (AOAC, 1997); (e) titratable acidity, which involved homogenization of pulp with deionized water followed by titration of the mixture (AOAC, 1997), expressed on a malic acid basis; (f) total soluble solids, which was determined using a digital refractometer (ATAGO Brasil, Ribeirão Preto, São Paulo, Brazil) (Tressler and Joslyn, 1961) after homogenization of pulp with deionized water. All analyses were performed in triplicate.

Mean daily temperatures, cumulative rainfall and daily sunlight were recorded at a meteorological station (Campbell Scientific, Logan, Utah, USA) located $6 \mathrm{~km}$ from the experimental site. The thermal sum in degree-days was calculated using $14{ }^{\circ} \mathrm{C}$ as the basal temperature (Ganry and Meyer, 1975). The clearness index, or atmospheric transmissivity, was calculated using the ratio of the global solar radiation at ground level and the extra-terrestrial solar radiation. The condition of the sky was classified according to Iqbal (1983) throughout the experimental period.

Data were analyzed by ANOVA (F-test) using the SISVAR statistical software, version 5.6. (Lavras, Minas Gerais, Brazil), and when significant, Tukey's test was used to compare the means of the different treatment groups. The level of significance was considered to be $5 \%(\mathrm{P} \leq 0.05)$.

\section{Results and discussion}

The bunch formation period had a significant $(\mathrm{P} \leq 0.05)$ impact on yield variables, but no significant influence was observed on the fruit diameter of the $1^{\text {st }}$ hand $($ mean $=3.43 \mathrm{~cm})$, the number of fruits on the $4^{\text {th }}$ hand (mean $\left.=17.91\right)$ or the length $($ mean $=19.09 \mathrm{~cm})$ and diameter $($ mean $=3.18 \mathrm{~cm})$ of the fruits on the last hand.

On average, the bunch-filling time was 45 days shorter in summer than in winter (Table 1). However, the mass of the bunch and stalk; the number of hands in the bunch; the mass, number and length of the fruits in the $1^{\text {st }}$ hand; and the mass, length and diameter of the fruits in the $4^{\text {th }}$ hand were higher in summer, while the mass and number 
of fruits in the last hand were higher in winter (Table 1). The greater mass and number of fruits observed in the last hand in winter was probably due to the overall fewer number of hands on the bunch, which probably favored the growth of the hands on the distal end of the bunch.

The difference in bunch mass between the bunch formation periods was $10.57 \mathrm{~kg}$, which was reflected in the greater number of hands and the masses of the $1^{\text {st }}$ and $4^{\text {th }}$ hands due to the better weather conditions in the summer (Table 1). The daily mean maximum and minimum temperatures in the summer were 29.70 and $20.53{ }^{\circ} \mathrm{C}$, respectively, and 23.63 and $14.22{ }^{\circ} \mathrm{C}$ in the winter, which resulted in a thermal sum of 907 summer degree days and 630 winter degree days. The total accumulated radiation was 1539 $\mathrm{MJ} \mathrm{m}^{-2}$ in the summer and $1355 \mathrm{MJ} \mathrm{m}^{-2}$ in the winter. Although the rainfall was more frequent in the summer than in the winter, the difference in accumulated rainfall between the two periods was small (approximately $64 \mathrm{~mm}$ ), as expected from the humid climate of the region. In summer, the skied were cloudy on 11 days, partly cloudy on 49 and open on 9, while in winter, 45 were cloudy; 74 were partly cloudy, and 9 were clear. Temperature and precipitation were higher and the most radiation was available in summer, which promoted greater biomass accumulation in the bunch and likely promoted a higher fruit-filling rate, resulting in a lower bunch-filling time in summer compared to winter (Table 1).

Bugaud et al. (2009) observed that banana plants of the variety 'Grande Naine' required a total radiation of $1270-1770 \mathrm{MJ} \mathrm{m}^{-2}$ for bunches to be harvested at different times of the year and in different regions of Martinique in the Caribbean. However, the thermal sum reached in these studies ranged from 950 to 1035 degree days, which does not include the thermal sum calculated for the winter.

There was no significant $(\mathrm{P} \leq 0.05)$ interaction between any of the bunch formation variables and the growth regulator treatments. The isolated effect of growth regulators was only significant $(\mathrm{P} \leq 0.05)$ for bunch-filling time (Figure 1), which increased by up to a week in the plants treated with growth regulators. However, this significant $(\mathrm{P} \leq 0.05)$ difference was only observed between

Table 1. Mean values of the bunch-filling time (BFT), bunch mass (BM), stalk mass (SM), hand number (HN), mass of the $1^{\text {st }}$ hand $\left(\mathrm{M} 1^{\text {st }} \mathrm{H}\right)$, fruit number of the $1^{\text {st }}$ hand $\left(\mathrm{FN} 1^{\text {st }} \mathrm{H}\right)$, fruit length in the $1^{\text {st }}$ hand $\left(\mathrm{FL} 1^{\text {st }} \mathrm{H}\right)$, mass of the $4^{\text {th }}$ hand $\left(\mathrm{M} 4^{\text {th }} \mathrm{H}\right)$, fruit length in the $4^{\text {th }}$ hand $\left(\mathrm{FL} 4^{\text {th }} \mathrm{H}\right)$, diameter of the fruit in the $4^{\text {th }}$ hand $\left(\mathrm{DF} 4^{\text {th }} \mathrm{H}\right)$, mass of the last hand $(\mathrm{MLH})$, and fruit number of the last hand (NFLH) as a function of the banana (Musa spp. AAA, cv. Nanica) bunch formation period.

\begin{tabular}{|c|c|c|c|c|c|c|}
\hline & $\begin{array}{l}\text { BFT } \\
\text { days }\end{array}$ & $\begin{array}{c}\mathrm{BM} \\
\mathrm{kg}\end{array}$ & $\begin{array}{c}\mathrm{SM} \\
\mathrm{kg}\end{array}$ & $\mathrm{HN}$ & $\begin{array}{c}\mathrm{M}^{\mathrm{st}} \mathrm{H} \\
\mathrm{kg}\end{array}$ & $\mathrm{FN} 1^{\text {st }} \mathrm{H}$ \\
\hline Summer & $82.9 \mathrm{~B}$ & $34.2 \mathrm{~A}$ & $2.9 \mathrm{~A}$ & $10.6 \mathrm{~A}$ & $4.7 \mathrm{~A}$ & $27.0 \mathrm{~A}$ \\
\hline Winter & $128.3 \mathrm{~A}$ & $23.6 \mathrm{~B}$ & $2.0 \mathrm{~B}$ & $8.3 \mathrm{~B}$ & $3.5 \mathrm{~B}$ & $22.4 \mathrm{~B}$ \\
\hline F & $1.764 .3^{* *}$ & $58.1 * *$ & $62.6^{* *}$ & $48.9^{* *}$ & $19.4 * *$ & $9.2 * *$ \\
\hline Mean & 103.9 & 29.3 & 2.5 & 9.5 & 4.1 & 24.9 \\
\hline \multirow[t]{2}{*}{ VC (\%) } & 3.8 & 16.7 & 18.5 & 12.5 & 25.4 & 22.7 \\
\hline & $\begin{array}{c}\mathrm{FL} 1^{\mathrm{st}} \mathrm{H} \\
\mathrm{cm}\end{array}$ & $\begin{array}{c}\mathrm{M}^{\text {th }} \mathrm{H} \\
\mathrm{kg}\end{array}$ & $\begin{array}{c}\mathrm{FL}_{4}^{\text {th }} \mathrm{H} \\
\mathrm{cm}\end{array}$ & $\begin{array}{c}\mathrm{DF} 4^{\text {th }} \mathrm{H} \\
\mathrm{cm}\end{array}$ & $\begin{array}{c}\text { MLH } \\
\text { kg }\end{array}$ & FNLH \\
\hline Summer & $24.0 \mathrm{~A}$ & $3.1 \mathrm{~A}$ & $23.9 \mathrm{~A}$ & $3.6 \mathrm{~A}$ & $1.6 \mathrm{~B}$ & $14.6 \mathrm{~B}$ \\
\hline Winter & $22.9 \mathrm{~B}$ & $2.6 \mathrm{~B}$ & $21.9 \mathrm{~B}$ & $3.4 \mathrm{~B}$ & $1.8 \mathrm{~A}$ & $15.5 \mathrm{~A}$ \\
\hline F & $6.5^{* *}$ & $12.1 * *$ & $31.1 * *$ & $17.5^{* *}$ & $6.9^{*}$ & $6.6^{*}$ \\
\hline Mean & 23.5 & 2.9 & 22.9 & 3.4 & 1.7 & 15.0 \\
\hline $\mathrm{VC}(\%)$ & 6.7 & 19.2 & 5.6 & 3.6 & 15.1 & 8.9 \\
\hline
\end{tabular}

Means in the same columns followed by the same letter do not differ significantly from each other according to Tukey's test $(\mathrm{P} \leq 0.05) ;{ }^{*}, \mathrm{P} \leq 0.05$ and ${ }^{* *}, \mathrm{P} \leq 0.01$ by an $\mathrm{F}$ test; $\mathrm{VC}$, variation coefficient. 
bunches treated with gibberellic acid and water, and there was no increase in bunch mass. In contrast to the results of this study, Kumar et al. (2011) observed that applying $200 \mathrm{mg} \mathrm{L}^{-1}$ of gibberellin to the bunch in the banana cv. Nanjanagudu Rasabale (AAB) at seven and thirty days after their emergence promoted an increase in the length and mass of the fruit and bunch mass and significantly reduced the days required for harvest. Biwas and Lemur (2014) also detected increased bunch mass and a reduction in the number of days to reach maturity in the banana fruits of cv. Robusta (AAA) treated with $50 \mathrm{mg} \mathrm{L}^{-1}$ of gibberellin one month after bunch emergence. Additionally, increased finger lengths and girths due to the application of $50 \mathrm{mg} \mathrm{L}^{-1}$ of gibberellin were reported in later studies by Mulagund et al. (2015) in the banana cv. Nedran (AAB).

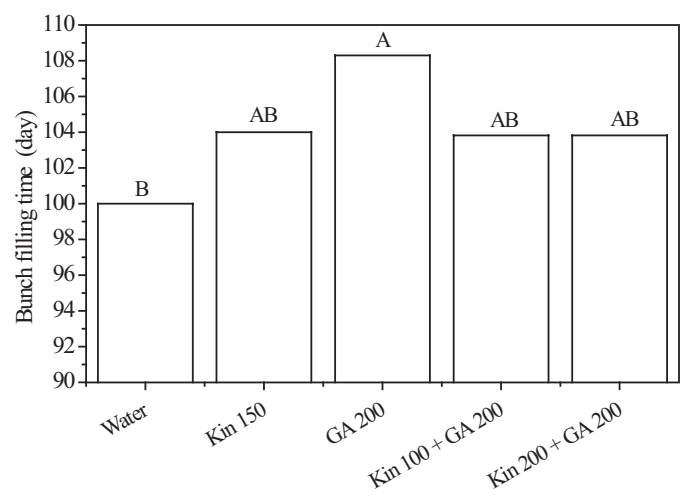

Figure 1. The effect of cytokinin and gibberellin on the duration of the banana (Musa spp. AAA, cv. Nanica) bunch-filling period. Means followed by the same letter do not differ significantly from each other according to Tukey's test $(\mathrm{P} \leq 0.05)$.

Jullien et al. (2001b) reported that the maximum diameter reached by a banana is directly related to the number of cells within the radius of the fruit, which in turn is dependent on cell division rates and the duration of cell division phase. This is consistent with the fact that the endogenous level of cytokinin is directly correlated with fruit growth and especially involved in the stimulation of cell division (Kumar et al., 2014). Gibberellins have been known to influence cell expansion by stimulating the expression of enzymes involved in the loosening of the cellular wall, thus increasing its plasticity (Marzouk and Kassem, 2011), as well as the genes that control cell division (Amber et al., 2012). Ding et al. (2013) suggested that cytokinins may induce parthenocarpy in tomato partially through the modulation of gibberellin metabolism. Together, this information supports the use of the growth regulators examined in this study.

The lack of a growth regulator effect in this study could be attributed to the development stage of the fruits at the time of application. The sprays were planned based on the results of Jullien et al. (2001a) with 'Grande Naine' bananas, which belong to the same group as the cv. 'Nanica', and the authors found that cell division ceased 350 degree days from the issuance of the inflorescence in the proximal fruits ( $1^{\text {st }}$ hand) and 420 degree days in the distal fruit bunch ( $7^{\text {th }}$ hand). However, even though cell division in the fruit stopped after the application of the growth regulators, there could have been some effect on cell expansion, which is also an essential factor in increasing the volume of fleshy fruit (Guo and Simmons, 2011).

Tee et al. (2011) observed that the length and diameter of the fresh fruit of Rastali bananas (Musa AAB) followed a similar trend to that observed in fresh fruit weight throughout fruit development, and three physiological stages (S1-S3) of sigmoid growth were identified. The growth rate was slow during S1 ( ${ }^{\text {st }}$ to 4 th week), rapid during $\mathrm{S} 2$ ( $^{\text {th }}$ to $10^{\text {th }}$ week) and remained constant during S3 (11 ${ }^{\text {th }}$ and $12^{\text {th }}$ week). During $\mathrm{S} 1$, the cells were small and compact, while the cell sizes were larger in S2, and starch granules were found in the innermost portion of the pulp cells. As the fruit developed to S3, the size of the parenchyma cells increased. The rapid growth of the banana fruits during S2 was attributed to the production of hormones at an optimum level, which supports the use of growth regulators to enhance cell expansion in the last hands of bunch.

Studies of the banana cv. Nanica are necessary to identify the critical period of fruit growth and 
cell division so that future applications of growth regulators can be better targeted at specific development stages.

For hormonal action to occur, there is need for amplification and signal transduction, a process that begins with the binding of the growth regulator to the membrane receptor. Thus, in addition to the presence of a receptor, additional assimilates must be available, and this is dependent on the activity of the source (leaves). Based on the mass of the bunch and fruit size the production of assimilates was limited in winter due to the weather (Table 1). In summer, the physiological condition appears to have been reversed because the mass of the bunch is considered high for the genotype in the region.

Cytokinin and gibberellin did not significantly affect the growth of the hands on the distal end of the bunch, where they were applied; in other words, their application failed to change the distribution model of the fruit size within the bunch. The position of the hand on the bunch had the greatest influence on the number and size of the fruits and the mass of the hand both when analyzed individually or through its interaction with the bunch formation period (Figure 2). Furthermore, there was a significant $(\mathrm{P} \leq 0.05)$ decrease in the mass of the hands along the bunch in the two bunch formation periods (Figure 2A). The difference in the mass of the hands between the bunch formation periods was only significant for the $1^{\text {st }}$ hand, which was heavier in summer than in winter. In the summer, there was a $34 \%$ reduction in mass from the $1^{\text {st }}$ to the $4^{\text {th }}$ hand and a $50 \%$ reduction from the $4^{\text {th }}$ to the last hand of the bunch. In winter, these mass variations were lower, 22 and $17 \%$, respectively.

In the summer, the number of fruits decreased significantly $(\mathrm{P} \leq 0.05)$ along the bunch, but in winter, significant differences could only be observed between the $1^{\text {st }}$ and $4^{\text {th }}$ hands
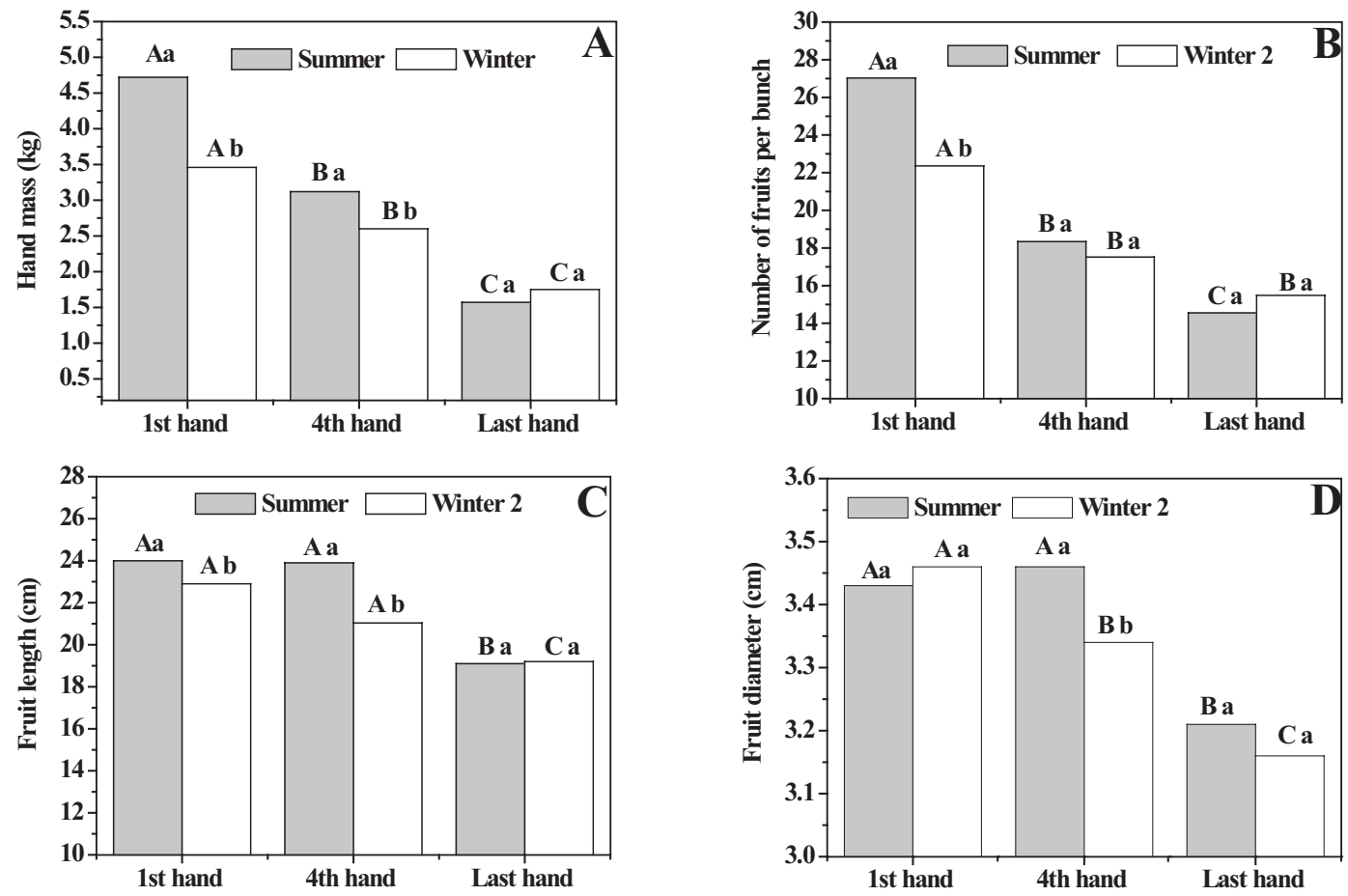

Figure 2. The effect of the interaction between the formation period and the hand position in the bunch on the hand mass (A), number of fruits per hand (B), length (C) and fruit diameter (D) of banana (Musa spp. AAA, cv. Nanica). Means followed by the same uppercase letters for bunch formation period or lowercase letters for hand position in the bunch do not differ significantly from each other according to Tukey's test $(\mathrm{P} \leq 0.05)$. 
(Figure 2B). The reduction in the number of fruits as a function of the position of the hand in the bunch suggests assimilates limitation during inflorescence differentiation. In the summer, there was a $32 \%$ reduction in the number of fruits from the $1^{\text {st }}$ to the $4^{\text {th }}$ hands and a $21 \%$ reduction from the $4^{\text {th }}$ to the last hand, while in winter, these reductions were 22 and $12 \%$, respectively (Figure 2B). However, these differences in the number of fruits were not significant between the two periods.

In the summer, there was no significant difference $(\mathrm{P} \leq 0.05)$ between the length of the fruit from the $1^{\text {st }}$ and $4^{\text {th }}$ hands, but a significant $(\mathrm{P} \leq 0.05)$ difference was observed between the $4^{\text {th }}$ and the last hand of the bunch (Figure 2C). In winter, there was a significant decrease $(\mathrm{P} \leq 0.05)$ in fruit length along the bunch. In the summer, the variation in fruit length from the $1^{\text {st }}$ to the $4^{\text {th }}$ hand was $0.42 \%$ and $21 \%$ from the $4^{\text {th }}$ to the last hand (Figure $2 \mathrm{C}$ ), and in winter, the respective variations in fruit length from the same hands were 4 and $12 \%$. These results show that, in both periods, the differences were greater in the last hands on the bunch, which is at odds with the variation in the mass of the hands. In the summer, no significant difference $(\mathrm{P} \leq 0.05)$ in fruit diameter was observed between the $1^{\text {st }}$ and $4^{\text {th }}$ hands, but a significant decrease was observed from the $4^{\text {th }}$ to the last hand of the bunch (Figure 2C). Variations in fruit diameter were much lower with values up to $7 \%$.

As there were no significant differences in the size, diameter and length of the fruits between the $1^{\text {st }}$ and $4^{\text {th }}$ hands in the summer, the variation observed in the mass of the hands can only be attributed to the number of fruits, while the differences observed between the $4^{\text {th }}$ and last hands of the bunch were due to both the number and size of the fruits (Figure 2). In winter, there were no significant differences $(\mathrm{P} \leq 0.05)$ in the number of fruits between the $4^{\text {th }}$ and last hands of the bunch, but the remaining differences were all significant, including those in fruit length and diameter. Thus, the variations in fruit size are believed to be more pronounced when there is limited photosynthate availability, such as in winter.

The postharvest characteristics of the fruits were not affected by the use of growth regulators during bunch development $(\mathrm{P} \leq 0.05)$. In contrast, Marzouk and Kassem (2011) reported improved physicochemical characteristics in grapes when vines were treated with cytokinin and gibberellin either indiviudally or in combination. Treating the banana cv. Nanjanagudu Rasabale (AAB) with 200 $\mathrm{mg} \mathrm{L}^{-1}$ increased the content of the total soluble solid sugars and soluble sugars by $2.1^{\circ}$ Brix and $3.28 \%$, respectively, which, in turn, reduced the titratable acidity in the pulp, indicating a change in carbohydrate metabolism. Given the inability of growth regulators to change the characters attributed to yield in this study, the absence of changes in the physicochemical characteristics was expected.

The postharvest life, mass loss, $\mathrm{pH}$, total soluble solids and titratable acidity were higher in fruits harvested in winter than in summer (Table 2), and

Table 2. Mean values of postharvest life (PL), luminosity (L), chromaticity $(\mathrm{C})$ and hue angle $\left(\mathrm{H}^{\circ}\right)$ of the peel color, mass loss (ML), total soluble solids (TSS), $\mathrm{pH}$ and titratable acidity (TA) of the pulp of ripe fruit as a function of the banana (Musa spp. AAA, cv. Nanica) bunch formation period.

\begin{tabular}{lcccccccc}
\hline & $\begin{array}{c}\text { PL } \\
\text { day }\end{array}$ & $\mathrm{L}$ & $\mathrm{C}$ & $\mathrm{H}^{\circ}$ & $\begin{array}{c}\text { PM } \\
\%\end{array}$ & $\begin{array}{c}\text { TSS } \\
{ }^{\circ} \text { Brix }\end{array}$ & $\mathrm{pH}$ & $\begin{array}{c}\text { TA } \\
\%\end{array}$ \\
\hline Summer & $7.5 \mathrm{~B}$ & $74.6 \mathrm{~A}$ & $52.1 \mathrm{~A}$ & $88.9 \mathrm{~A}$ & $2.4 \mathrm{~B}$ & $21,6 \mathrm{~B}$ & $0.5 \mathrm{~B}$ & $0.5 \mathrm{~B}$ \\
Winter & $18.7 \mathrm{~A}$ & $66.9 \mathrm{~B}$ & $48.8 \mathrm{~B}$ & $87.4 \mathrm{~B}$ & $6.1 \mathrm{~A}$ & $23,7 \mathrm{~A}$ & $0.6 \mathrm{~A}$ & $0.6 \mathrm{~A}$ \\
\multicolumn{1}{c}{$\mathrm{F}$} & $275.4^{* *}$ & $524.6^{* *}$ & $9.4^{* *}$ & $20.0^{* *}$ & 271.3 & $44.8^{* *}$ & $9.3^{*}$ & $34.4^{* *}$ \\
\multicolumn{1}{c}{ Mean } & 12.8 & 71.0 & 50.5 & 88.2 & 4.2 & 22,65 & 0.5 & 0.5 \\
VC (\%) & 19.3 & 1.7 & 9.9 & 1.4 & 19.2 & 4.9 & 13.6 & 13.6 \\
\hline
\end{tabular}

Means in the same columns followed by the same letters do not differ significantly from each other according to Tukey's test $(\mathrm{P} \leq 0.05) ;{ }^{*}, \mathrm{P} \leq 0.05$ and ${ }^{* *}, \mathrm{P} \leq 0.01$ by an $\mathrm{F}$ test; $\mathrm{VC}$, variation coefficient. 
these results probably reflect the climatic conditions during bunch development. The lower maximum, minimum and mean temperatures observed in winter are likely to have promoted less intense metabolic activity during fruit development, which extended to the postharvest stage and consequently resulted in lower total water loss by the fruits. In fact, if the total water loss was expressed per day, the water loss rate would have been the same for fruits harvested in summer and winter. Umber et al. (2011) confirmed that the thermal sum is closely linked to the green life of a banana, which is consistent with the fact that fruits harvested in winter exhibit a longer postharvest life (Table 2). The higher levels of soluble solids and titratable acidity can be attributed to the greater bunchfilling time in winter, which was 45 days longer than in summer, or they may be related to the induction of tolerance to low temperature (Tables 1 and 2). Bugaud et al. (2009) also observed that bananas harvested during the hot, rainy season had the lowest levels of total soluble solids, while bananas harvested during the cool, dry season had the highest content of total soluble solids in the fruit pulp. The lower levels of luminosity, chromaticity and hue angle in the peel of ripe fruits harvested in winter were a consequence of 19 days of temperatures below $10^{\circ} \mathrm{C}$ that caused browning of the peel due to oxidation and the polymerization of phenols (Hashim et al., 2013).

In conclusion, independent of the bunch formation period, cytokinin and gibberellin do not affect the size and physicochemical characteristics of the fruit of the banana cv. Nanica (AAA).

\section{Acknowledgments}

To Fundação de Amparo à Pesquisa do Estado de São Paulo, Brazil (FAPESP) for the research grant given to the second author (2012/16614-5).

\section{Resumen}

J.D. Lima, J. Santa Rosa, E.N. Gomes, D.E. Rozane y S.H. Modenese-Gorla da Silva. 2016. Características de los frutos de banano (Musa spp. AAA, cv. Nanica) tratados con citoquinina y giberelina. Cien. Inv. Agr. 43(2):223-232. El objetivo de este trabajo fue analizar el efecto de la citoquinina y de giberelinas en las características de los frutos de banano (Musa spp. AAA, cv. Nanica), en función del período de formación y la posición en el racimo. Se adoptó un diseño experimental completamente al azar, con arreglo factorial $2 \times 5$, dos períodos de desarrollo del racimo (verano e invierno) y cinco tratamientos o, el mismo diseño en parcelas subdivididas, considerando en la parcela el arreglo factorial $2 \times 5$, y en la subparcela, la posición de la mano en el racimo (basal, mediana y apical). Los tratamientos constituyeron dos pulverizaciones con agua, $150 \mathrm{mg} \mathrm{L}^{-1}$ de cinetina, $200 \mathrm{mg} \mathrm{L}^{-1}$ de ácido giberélico, 100 mg L ${ }^{-1}$ de cinetina más $200 \mathrm{mg} \mathrm{L}^{-1}$ de ácido giberélico y $200 \mathrm{mg} \mathrm{L}^{-1}$ de cinetina más $200 \mathrm{mg}$ $\mathrm{L}^{-1}$ de ácido giberélico, aplicados desde la cuarta hasta la última mano del racimo. El período de formación del racimo influye sobre el tiempo de llenado, el peso del racimo y del tallo, el número de manos, el número de frutos por mano y el tamaño del fruto, dependiendo de la posición que ocupa en el racimo, así como la vida poscosecha, la pérdida de masa, el color de la cáscara, el pH, el contenido de sólidos solubles y la acidez valorable de pulpa. Citoquinina y giberelina, en la forma que fueron aplicadas no influyeron en la producción, calidad, tamaño de y rendimiento fruta. La posición en el racimo tuvo una fuerte influencia en el tamaño y número de frutos por mano.

Palabras clave: Relación fuente-sumidero, reguladores de crecimiento, variabilidad intraracimo. 


\section{References}

Alvares, C.A., J.L. Stape, P.C. Sentelhas, J.L.M. Gonçalves, and, G. Sparovek. 2013. Köppen’s climate classification map for Brazil. Meteorol Z. 22: 711-728.

Amber, L., T. Ariizumi, and C.M. Steber. 2012. Gibberellin signaling: a theme and variations on DELLA repression. Plant Physiol. 160: 83-92.

AOAC. 1997. Official methods of analysis of the Association of Analytical Chemists. 13. ed. AOAC, Washington. $1018 \mathrm{pp}$.

Biwas, P.K., and K. Lemtur. 2014. Effect of growth regulators and certain organic sprays on bunch characters in banana cv. Robusta. Asian J. Hort. 9: 269-271.

Bugaud, C., M.O. Daribo, M.P. Beauté, N. Telle, and C. Dubois. 2009. Relative importance of location and period of banana bunch growth in carbohydrate content and mineral composition of fruit. Fruits 64: 63-74.

Ding J., B. Chen, X. Xia, W. Mao, K. Shi, Y. Zhou, and J. Yu. 2013. Cytokinin-induced parthenocarpic fruit development in tomato is partly dependent on enhanced gibberellin and auxin biosynthesis. Plos One 8: 1-11.

Ganry, J., and J.P. Meyer. 1975. Recherche d'une loi d'action de la température sur la croissance des fruits du bananier. Fruits 30: 375-392.

Guo, M., and C. R. Simmons. Cell number counts The fw2.2 and CNR genes and implications for controlling plant fruit and organ size. 2011. Plant Sci. 181: 1-7.

Iqbal, M. 1983. An introduction to solar radiation. Academic Press. Canada. 390 pp.

Hashim, N., M. Pflanz, C. Regen, R.B. Janius, R. A. Rahman, A. Osman, M. Shitan, and M. Zude. 2013. An approach for monitoring the chilling injury appearance in bananas by means of backscattering imaging. J. Food Eng.116: 28-36.

Huang, H., G. Jing, H. Wang, X. Duan, H. Qu, and Y. Jiang. 2014. The combined effects of phenylurea and gibberellins on quality maintenance and shelf life extension of banana fruit during storage. Sci. Hort. 167: 36-42.
Jullien, A., E. Malézieux, N. Michaux-Ferrière, M. Chillet, and B. Ney. 2001a. Within-bunch variability in banana fruit weight: importance of developmental lag between fruits. Annals Bot. 87: 101-118.

Jullien, A., N.G. Munier-Jolain, E. Malézieux, M. Chillet, and B. Ney. 2001b. Effect of pulp cell number and assimilate availability on dry matter accumulation rate in a banana fruit [Musa sp. AAA group 'Grande Naine' (Cavendish subgroup)]. Annals Bot. 88: 321-330.

Kumar, C.P.N., B.N. Sathyanarayana, P. Naresh, and M. Lakshmipathy. 2011. Effect of certain pre harvest treatments in improving the yield and quality of banana cv. Nanjanagudu Rasabale. Plant Arch. 11: 667-681.

Kumar, R., A. Khurana, and A.K. Sharma. 2014. Role of plant hormones and their interplay in development and ripening of fleshy fruits. J. Exp. Bot. 65: 4561-4575.

Li, X.-X., F. Kobayashi, H. Ikeura, and Y. Hayata. 2011. Chlorophenoxyacetic acid and chloropyridylphenylurea accelerate translocation of photoassimilates to parthenocarpic and seeded fruits of muskmelon (Cucumis melo). J. Plant Physiol. 168: 920-926.

Marzouk, H.A., and H.A. Kassem. 2011. Improving yield, quality, and shelf life of Thompson seedless grapevine by preharvest foliar applications. Sci. Hort. 130: 425-430.

Mulagund, J., K. Kumar, S. Soorianathasundaram, and H. Porik. 2015. Influence of post-shooting sprays of sulphate of potash and certain growth regulators on bunch characters and fruit yield of banana cv. Nedran) (French Plantain Musa AAB). The Bioscan 10: 153-159.

Niu, Q., T. Wang, J. Li, Q. Yang, M. Qian, and Y. Teng. 2015. Effects of exogenous application of $\mathrm{GA}_{4+7}$ and N-(2-chloro-4-pyridyl)-N'-phenylurea on induced parthenocarpy and fruit quality in Pyrus pyrifolia 'Cuiguan'. Plant Growth Regul. 76: 251-258.

Soil Survey Staff. 2010. Keys to soil taxonomy. 7 ed. USDA-Natural Resources Conservation Service. Washington. 346 pp.

Tressler, D. L., and M.A. Josly. 1961. Fruits and vegetables juice-processing technology. The AVI Publications. Westport. 1028 pp. 
Tee, Y.K., P. Ding, and N.A.A. Rahman. 2011. Physical and cellular structure changes of Rastali banana (Musa AAB) during growth and development. Sci. Hort. 129: 382-389.

Umber, M., B. Paget, O. Hubert, I. Salas, F. Salmon, C. Jenny, M. Chillet, and C. Bugaud. 2011. Application of thermal sums concept to estimate the time to harvest new banana hybrids for export. Sci. Hort. 129: 52-57.
Von Loesecke, H.W. 1950. Bananas. 2 ed. Interscience Publish Inc. New York. 189 pp.

Zhang, C., and M.D. Whiting. 2011. Improving 'Bing' sweet cherry fruit quality with plant growth regulators. Sci. Hort. 127: 341-346.

Zhang, C., and M.D. Whiting. 2013. Plant growth regulators improve sweet cherry fruit quality without reducing endocarp growth. Sci. Hort. 150: 73-79. 